\title{
The Legal Persona: An Essay on the Professional Mask
}

James R. Elkins

West Virginia University College of Law, james.elkins@mail.wvu.edu

Follow this and additional works at: https://researchrepository.wvu.edu/law_faculty

Part of the Law and Society Commons, and the Legal Profession Commons

\section{Digital Commons Citation}

Elkins, James R., "The Legal Persona: An Essay on the Professional Mask" (1978). Law Faculty

Scholarship. 15.

https://researchrepository.wvu.edu/law_faculty/15

This Article is brought to you for free and open access by the WVU College of Law at The Research Repository @ WVU. It has been accepted for inclusion in Law Faculty Scholarship by an authorized administrator of The Research Repository @ WVU. For more information, please contact ian.harmon@mail.wvu.edu. 


\title{
THE LEGAL PERSONA: AN ESSAY ON THE PROFESSIONAL MASK
}

\author{
James R. Elkins*
}

$7 \mathrm{HE}$ legal profession offers little opportunity for the practitioner to analyze the fundamental constructs underlying the legal system or the dynamics of the lawyering process. Jurisprudence and legal education traditionally have emphasized the external aspects of law, implying that man is a rational decisionmaker who freely controls his life and shapes societal institutions. ${ }^{1}$ This approach is unrealistic because it neglects the psychological dimension of man and the complexity of man's behavior. ${ }^{2}$ Jurisprudential scholars and legal educators should recognize that a growing body of sophisticated literature in linguistics and anthropology as well as social psychology and psychiatry is also relevant to the study of

* Associate Professor of Law, West Virginia University, College of Law; A.B., University of Kentucky, 1967; J.D., University of Kentucky, 1971; LL.M., Yale University, 1975.

This essay would not have been written but for the innovative and creative work of my friend, teacher, and counselor, John Batt. This piece is at hest a frail reflection of his enigmatic, Dionysian, and Protean spirit.

' Anglo-American jurisprudence traditionally has rested on a liberal social ideology that assumes both individual free will and a clear division between thought and deed.

Historically it has been one of the tasks of liberalism to defend the distinction between a man's mind and his actions, his intentions and his deeds; otherwise there seemed a danger of the individual not being able to defend himself against state action. Hence the well-known maxim from English law that "the thought of man is not tryable; the Devil alone knows the thought of man." To judge the soul of a man, instead of his actions, seemed to open the way to tyranny. . . . This characteristic attitude can be traced throughout liberal legal theory. It was one reason for Justice Holmes's insistence on external standards in criminal liability, since morals concern the "actual internal state of the individual's mind, what he actually intends."

P. Roazsn, Frgud: Polutical and Social Thought 58 (1st ed. 1968) (footnote omitted).

2 One voice rebelling against jurisprudential thinkers who do not understand the psychological dimensions of man is Professor John Batt. He has described jurisprudence as the "unsexed servant of repression" and condemned the contemporary philosopher of law for his ohsession "with order, rationality, logic, and predictability." Batt, They Shoot Horses, Don't They?: An Essay on the Scotoma of One-Eyed Kings, 15 U.C.L.A. L. Rev. 510, 548 (1968). See also E. Robinson, LAw aNd THE Lawyers 73 (1935); Batt, Notes from the Penal Colony: A Jurisprudence Beyond Good and Evil, 50 Iown L. Rev. 999 (1965). Batt rallies the cry against:

Jurisprudes [who] calk up the fissures in their logical castles of absurdity, rumble about nonideological principles of law, acro-arc through logico-linguistic feats of verbomania, distinguish "is" from "ought," lust after the "pure law," or dispense sweet allegories about the Light of the Law that failed the Virgin Lady of the Lake[.] Id. at 999-1000 (footnote omitted). 
the lawyer in society. This essay adopts a socio-psychological frame of reference and explores the images and guises of the lawyer as a professional in an attempt to add a new perspective to contemporary philosophy of lawyering.

I.

Positing a "legal persona,"3 as the title of this essay suggests, presumes that lawyers possess certain characteristics that set them apart as a group. ${ }^{4}$ Whether lawyers in fact have a special identity depends on the answer to two questions. First, do lawyers present themselves to the world in a way that calls attention to themselves as lawyers? ${ }^{5}$ Second, do lawyers perceive themselves as different from other professionals? Arguably, lawyers represent themselves to the world and are perceived by the world through images. That is, in the "presentation of self in everyday life," the self is not shown but only a reflection or image of the self. For the individual lawyer, this image is a mask of the true self-a persona-which defines his professional identity for himself and for society. In addition, owing to his professional training, the lawyer conceives of himself as " $a$

3 "Persona" was the name given to the mask worn by an actor in Greek drama to signify the role that he played. G. Aluport, Personality: A Psychological Interpretation 25 (1937). The legal persona described in this essay is a kind of profile or social character, not an empirical constrnct. It is based on the author's exposure to lawyers, judges, law teachers, and law students.

This article will not attempt to explore the problem of what it is to act like a lawyer except to note that it involves a sense of restraint in action. One commentator finds the "skill of restraint . . . rooted in the tradition of law." Christenson, Studying Law As the Possibility of Principled Action, 50 DEN. L.J. 413, 432 (1974). As a personal style, restraint may be a factor in becoming a successful law student. See Kennedy, How the Law School Fails: A Polemic, 1 Yale Rev. L. \& Soc. Act. 71, 77 (1970).

4The initial presumption of this essay of a single legal "persona" simplifies reality. Lawyers play such diverse roles that placing all lawyers together for purposes of any characterization is problematic. For example, law-trained sociologist David Reisman has noted that "the law-trained person is likely to be found almost anywhere in the American social structure." Reisman, Law and Sociology: Recruitment, Training and Colleagueship, 9 STAN. L. Rev. 643, 645 (1957). The multiplicity of lawyering roles strains yet need not destroy the validity of the presumption that there exists a general legal persona, which may be the subject of inquiry.

3 Sociologist Erving Goffman has commented that:

Whatever an individual does and however he appears, he knowingly and unknowingly makes information available concerning the attributes that might be imputed to him and hence the categories in which he might be placed. The status symbolism in his "personal front" provides information about his group and aggregate affiliations; his treatment at the hands of others conveys a conception of him; the physical milieu itself conveys implications concerning the identity of those who are in it.

E. GoffMan, ENCOUNTERS 102 (1961).

- E. Goffman, The Presentation of Self in Everyday Life (1959). 
special kind of person both different from and somewhat better than those nonprofessional members of the social order." The lawyer's perception of himself as a lawyer and his perception of his role in society begin to crystallize during his first days in law school. Confronted with the Socratic method of teaching that obliges him to master a new form of reasoning, the law student begins to adjust his view of the world to accord with his changed environment. And through the persuasive efforts of law professors and older law students, the prospective lawyer realizes that he must learn to "talk like a lawyer" and to "think like a lawyer" to become a lawyer.

\section{A. Talking Like a Lawyer}

From the public's perspective, lawyers speak an arcane language, commonly termed "legalese." In a vehement attack on legalese, written almost forty years ago, Fred Rodell ${ }^{8}$ argued that while a lawyer deals with ordinary facts and occurrences of business, government, and living, he nevertheless uses "a jargon which completely baffles and befoozles the ordinary literate man . ..." Rodell berated lawyers for their use of "professional pig Latin" and their failure to relate legal concepts to clients in simple English. ${ }^{10}$

[T] he lawyers' trade is a trade built entirely on words. And so long as the lawyers carefully keep to themselves the key to what those words mean, the only way the average man can find out what is going on is to become a lawyer, or at least to study law, himself. All of which makes it very nice-and very secure-for the lawyers."11

Whatever the justice of Rodell's indictment, his analysis highlights the way a lawyer's language sets him apart from the general population. Although the bare use of jargon, of course, does not distinguish the lawyer from other professionals, the centrality of interpreting and manipulating language to resolve most legal problems makes verbal dexterity essential for successful lawyering. ${ }^{12}$ The legal persona finds its voice in the technical language of the law, through such terms as mens rea, due process, void ab initio, and inter vivos trust. Even in the use of standard English, the lawyer

7 Wasserstrom, Lawyers as Professionals: Some Moral Issues, 5 Human Rigrits 1, 18 (1975).

F. RODELL, WOE UNTO You, Lawyers! (1939).

'Id. at 7.

19 Id. at 8-9.

"Id. at 9.

12 See W. Probert, Law, Language and Communication 7 (1972); J. Stone, Law and the Social Sciences in the Second Half Century 57 (1966). 
sometimes uses the layman's meaning and at other times gives the words special legal meaning. ${ }^{13}$ The lawyer's ability to shift meanings of words reinforces the need for both a common and special vocabulary and emphasizes the importance of precision in the use of technical terms. Thus, learning and mastering the subtleties of legal language are an integral part of the socialization and professionalization of the lawyer. ${ }^{14}$

\section{B. Thinking Like a Lawyer}

Theorizing that lawyers have a unique way of thinking suggests that they have a singular view of the world that shapes their interaction with clients and their approach to problem solving. Social scientists believe:

Each of us creates a representation of the world in which we live-that is, we create a map or model which we use to generate our behavior. Our representation of the world determines to a large degree what our experience of the world will be, how we will perceive the world, what choices we will see available to us as we live in the world. ${ }^{15}$

Thus our world view ${ }^{18}$ (or Weltanschauung) controls not only the

13 For example, reasonable man, substantial evidence, proximate cause, negligence, complaint, and self-defense are all reasonably intelligible words but have both their plain and special meaning to the lawyer. The lawyer must be aware of both these meanings and perceive whether they are being used in their special or their ordinary sense. Probert \& Brown, Theories and Practices in the Legal Profession, 19 U. FuA. L. REv. 447, 470-71 (1966-1967). See also J. STONE, supra note 12 , at 62.

"See Probert, Law Through the Looking Glass of Language and Communicative Behavior, 20 J. Legal Educ. 253 (1968):

A lawyer's professionalization seems to include learning "to talk like a lawyer," not by learning just rules but also special concepts and doctrines with definitional and logical interrelationships, adding up to a syntax of a unique kind. Even though law school materials emphasize common law, still, these verbalisms seem to be transcended by a lawyer approach with language that finds its way into wills, contracts, and various instruments as well as into a lawyer's thinking, telking, and writing in a way that heavily influences how he acts.

Id. (footnote omitted).

See generally W. Bishin \& C. Stone, Law, Language, and Ethics 403-15 (1972); J. Frank, Courts on Trial 171-76 (1949); I. Mehler, Efrective Legal Commumcation 3-20 (1975); D. Mellinkopr, The Language of the Law 201-82 (1963); Allen, The Dynamics of Interpersonal Communication and the Law, 3 WASHBuRN L.J. 135, 138-43 (1964); Eisele, The Legal Imagination and Language: $A$ Philosophical Criticism, 47 U. CoLo. L. REv. 363 (1976); Rutter, $A$ Jurisprudence of Lawyers' Operations, 13 J. Legal Educ. 301, 318-24 (1961).

is 1 R. Bandler \& J. Grinder, The Structure of Magic 7 (1975). See R. Rediteld, The Primitive World and Its Transformattons 85-87 (1953).

1" The concept of world view has been described from various perspectives. Several different disciplines use terms closely related to the concept of world view as used here: "conceptual 
way we represent the world to ourselves but also the way we experience the world. ${ }^{17}$

What attributes of lawyers and lawyering create a special "world view"? ${ }^{18}$ Simply stated, the lawyer considers himself a neutral, ${ }^{10}$ rational, ${ }^{20}$ and objective problem solver. ${ }^{21}$ As a rational thinker, the lawyer perceives client problems, clients, and self through the mist of legal rules and legal problems. In essence, a lawyer's way of thinking and representing certain events in the world consists of a dislike of vague generalities, the structuring of all possible human relations into the form of claims and counterclaims, and the belief that

systems," Harvey, Conceptual Systems and Attitude Change, in ATT1Tude, EgoINVOLVEMENT, AND ChaNGe 201, 201-06 (C. Sherif \& M. Sherif eds. 1967); "cognitive style," Nisbett \& Temoshok, Is There an "External" Cognitive Style?, 33 J. PErs. \& Soc. Psych. 36, 36 (1976); "belief system," Converse, The Nature of Belief Systems in Mass Publics, in IDEOLOGY AND DiscontinET 206, 206-07 (D. Apter ed. 1964); "ideology," IDEology aNd Discontent (D. Apter ed. 1964); "cosmology," M. Douglas, Natural Symbols 144 (1973).

On the significance of the concept of world view in anthropology, see G. FoSTRR, TziNtzuntzan Mexican Peasants in a Changing World 11-12 (1967); E. Hobbri, Man in the Primitive World 158-59 (2d ed. 1958).

17 See E. EruKson, ToYs and Reason 141 (1977).

Erikson describes world view as "an all-inclusive conception which, when it is historically viable, integrates a group's imagery." Accordingly, "it focuses disciplined attention on a selection of verifiable facts; it liberates a joint vision which enhances a sense of historical reality; and it actualizes a widening fellowship with strong work commitments." E. ERIKson, supra at 148.

is "That lawyers have particularly pronounced intellectual habits peculiar to them has often heen noticed, especially by historians and other students of society . ..."J. SHKLAR, Lzonuism 9 (1964). See also M. Barkun, LaW WTrhout Sanctions 77 (1968).

"One of the most prevalent myths in the legal system is the myth of neutrality, symbolized by blindfolded justice. One manifestation of this myth is the persistent dream that the judicial process is neutral. See, e.g., Wechsler, Toward Neutral Principles of Constitutional Law, 73 Harv. L. Rgv. 1 (1959). Professors Arthur Miller and Ronald Howell, however, drawing upon the leading commentators in philosophy, sociology, history, science, and theology have concluded that neutrality and objectivity in decisionmaking are not attainable. Law and the decisional process by which it is invoked and applied are not value-free. "[V]alue preferences mescapably intrude to guide decisions made among competing alternatives." See Miller \& Howell, The Myth of Neutrality in Constitutional Adjudication, 27 U. CHr. L. REv. $661,665(1960)$.

20 The myth of rationality in the legal profession is founded on a model of human behavior seriously at odds with modern psychology. Like classical economic theory, it views man as totally rational and influenced in his decisionmaking only by external objective factors. Lawyering is in some part, however, defined by the individual's unconscious and the collective consciousness of the legal profession. Lawyers and jurisprudential scholars have lost sight of the dynamic reciprocity between the conscious and the unconscious modes of thought. See generally T. Scheluing, The Strategy of Conflict 16-19 (1963).

21 "Legal thinking, like all purposive thinking, is directed toward the solution of problems. Clients and courts ask questions. The lawyer must find answers." C. MORRIs, How LawYERS TyINK 3 (1938). 
human conflicts can be settled under established rules in a judicial proceeding. ${ }^{22}$

Judith Shklar has labeled this professional view of the world "legalism." She defines it as "the ethical attitude that holds moral conduct to be a matter of rule following, and moral relationships to consist of duties and rights determined by rules." ${ }^{23}$ In the final sense, legalism is "a way of thinking about social life, a mode of consciousness" that structures the lawyer's social experience ${ }^{24}$ and prescribes a code of conduct for individual lawyers. ${ }^{25}$

Legalism also creates and molds the lawyer's legal persona. ${ }^{26}$ "The legal view is no more narrowing than any other unidimensional explanation of the world; yet it is "more deluding than some other world views" in "its covert character."27 Law professors and lawyers erroneously believe that their legal training and their intel-

2 J. Auerbach, Unequal Justice 10 (1976). See also S. Scheingold, The Politics of Rights 153 (1974).

23 J. ShKLAR, supra note 18, at 1. Judith Shklar's work on legalism indicts the effort to separate law and morality. For a criticism of lawyer attitudes in the lawyer-client relationship, see Wasserstrom, supra note 7, at 1. See also Chroust, Law: Reason, Legalism, and the Judicial Process, 74 Errics 1 (1963); Friedman, On Legalistic Reasoning-A Footnote to Weber, 1966 W1s. L. REv. 148. For an exploration of the effect of "legalism" on the attorneyclient relationship and counseling alternatives, see, for example, A. WATSON, THE LAWYER IN THE INTERviewing ANd Counselutng Process (1976); Elkins, A Counseling Model for Lawyering in Divorce Cases, 53 Notre Dame Law. 229, 229-33 (1977).

${ }^{24} \mathrm{R}$. Unger, KNowledge AND PolTics 75 (1975). One commentator has suggested that an ideological view premised on legalism "is as much an obscuring veil as a clarifying lens for approaching social problems. Law and legal thinking are as frequently the cause of social trouble as the means of resolving it." D'Errico, "The Law Is Terror Put into Words," 2 LEARning \& L. 1, Fall 1975, at $39,40$.

Jerold Auerbach has also indicted the legal profession for its failure to promote social justice in this country. Auerbach contends that this failure is due, in part, to legal minds "hemmed in by the ingrained professional preference for process and order, moderation and compromise." J. AuERBACH, supra note 22, at 266.

${ }^{25}$ See J. SHKLAR, supra note 18 , at $1,5,8$.

27 An interesting example of the internalization of legal concepts is the legal profession's recurrent attempt to achieve certainty in the law. The result of these attempts has been "system construction, the attempt to account for all occurrences within an all-encompassing framework of laws and principles and to deny to the individual any role in shaping events." W. Volkomer, The Passionate Ltberal: The Political and Legal Ideas of Jerome Frank 25 (1970) (footnote omitted). Jerome Frank has suggested that this desire to achieve certainty reflects an unconscious wish to find in law a substitute for the firmness, certainty, and infallibility ascribed in childhood to the parent. J. Frank, LAw AND THE ModERN MIND 3-21 (1930). See Bienenfeld, Prolegomena to a Psychoanalysis of Law and Justice, (pt. 1) 53 CALIP. L. REv, 957, 989-99 (1965). See also J. Flügel, MAN, Morals and Society 52-58 (1945); A. Kardiner, The Individual and His SocteTy 32 (1939); Redmount, Psychological Views in Jurisprudential Theories, 107 U. PA. L. REv. 472, 504-05 (1959); Schoenfeld, The Superego's Influence on the Law, 14 DE PAUL L. REv. 299, 307-08 (1965).

2 S. ScHeingold, supra note 22 , at $160-61$. 
lectual tools will enable them "to strip a problem, any problem, down to its essentials."28 The socialization process begun in law school $^{29}$ creates and provides the lawyer with a new model of the world-a world of rights and obligations, liabilities, and causes of action-which excludes much from its vision. As Professor Scheingold has noted: "When we accuse someone of being legalistic, we suggest an excessive zeal for purely formal details which becloud rather than clarify the real issue. The legalist is someone who is lost among the trees and cannot or will not consider the overall shape of the forest." 30 The process of "thinking like a lawyer" thus provides no basis for critically analyzing and assessing the assumptions underlying the lawyer's peculiar view of the world..$^{31}$

\section{Relationship Between "Thinking" and "Talking" Like a Lawyer-A Subjective View of the Legal Process}

Although the use of legal language and thinking like a lawyer have been explored thus far independently, these segments of the legal persona are intertwined because the existence and structure of legal language make it possible to think like a lawyer..$^{32}$ Legal language

2s Id. at 161.

It was the proudest boast of law scbools to train students to think like lawyers. This process entailed a highly stylized mode of intellectual activity that rewarded inductive reasoning, analytical precision, and verbal felicity. But relentless doctrinal analysis of appellate opinions severely restricted the range and depth of inquiry. Craft was rewarded over choice and process over purpose. Thinking like a lawyer required the application of technical skills to the task of problem-resolution witbin the confines of the adversary system. Justice, it was assumed, emerged inevitably from the confrontation of skilled advocates in an adversary setting. Legalism instilled "laissez-faire morality" in its converts: the presumption that proper decisions were the decisions that the legal system produced.

J. AUBRBACH, supra note 22, at 276 (footnote omitted).

Both the legal profession and legal education promote and maintain legalism as a world view. Scheingold argues that there is "a world view implicit in the paradigm that structures legal education ... [e.g.,] the student is provided with an approach which seems to both explain and justify the working of the American system." S. ScHEINGoLD, supra note 22, at 158. See note 28 supra.

- S. Scheingold, supra note 22, at 153.

"For a presentation of radical alternatives, see Bonsignore, At the Edge of Law, $11 \mathrm{AM}$. Bus. L.J. 135 (1973); Savoy, Toward a New Politics in Legal Education, 79 YAle L.J. 444, 455-504 (1970).

2 For an illuminating discussion of the relationship between legal language and "thinking like a lawyer," see J. White, The Legal. Imagination (1973). In considering how language structures one's world, Professor White poses a series of thoughtful questions concerning the role of language in the lawyering process. He asks whether the peculiarities that we observe in the lawyer's use of and experience with language

reside in the existence of a discrete professional language, with its own vocabulary and 
is the medium through which the forms and categories of events can be made meaningful within the legal system. The legal persona communicates, analyzes and classifies problems, and structures relationships based on these linguistic categories:

[A lawyer] mentally converts events and transactions into the vocabulary and the pigeon holes of a classification system which pervades the whole corpus of the law. Thus a certain exchange of communications between persons may be seen by the lawyer as an "offer" and an "acceptance" forming a "contract." . . If one of the persons involved was a seventeen year old boy, the lawyer translates this fact into "minor," and a cluster of concepts follows along with it. Lawyers instinctively engage in this process of mental categorization and classification..$^{33}$

A lawyer's world view acts as a perceptual screen for incoming sensory data. ${ }^{34}$ Language concepts screen and structure one's perception and allow one to organize information and experiences. ${ }^{35}$ Through these concepts or "perceptual categories," one abstracts and maps physical and social reality..$^{36}$ At the most rudimentary level of perception then, what the lawyer characterizes as "out

syntax? Or in habits of mind and ways of working that find expression in whatever -verbal language the lawyer uses, even when he is talking, say, to his client or to a jury in ordinary English? And most serious of all: what relationship can the lawyer establish with these patterns of thought and language that he uses? Can he simply learn to use and master them without being somewhat affected-perhaps controlled-by what he has learned? To put the question in even larger terms: what is the relationship between the lawyer's language and his mind?

Id. at 5 .

${ }^{3}$ Meador, The Mind of the Lawyer, or Why Doctors Should Not Have Trouble with Lawyers, 22 ALA. L. REv. 503, 505 (1970). See also C. MorfIS, supra note 21, at 75-94.

$34 \mathrm{~S}$. GREer, The Logic of Social INquiry 30 (1969).

Since there is neither space for storing nor time for reviewing an indefinitely large number of unique memories, somehow the organism must operate on a more schematic basis. Out of the diversity and uncertainty the organism must be able to extract the essence of an object. . . . Efficient perception therefore depends on objects and situations have recurrent properties; that is, properties that occur together with reasonable frequency in the environment.

Kaplan, Cognitive Maps in Perception and Thought, in Image and Environment 63, 67 (R. Downs \& D. Stea eds. 1973).

is Linguist B.L. Whorf has argued forcibly that our language influences the manner in which the individual or larger cultural group labels reality and behaves with respect to it. His persuasive hypothesis is that different cultures perceive and conceive reality in different ways and that the language spoken by members of a culture shapes the coguitive structure of the individual speaking that language. Whorf, The Punctual and Segmentative Aspects of Verbs in Hopi, in Language, Thought, and RealtTy 51, 55 (J. Carroll ed. 1956). See also J. Britton, Language and Learning 11-32 (1970); C. Mueller, The Politics of Communication 16 (1973).

36 See M. BARKUN, supra note 18 , at 79 . 
there" is not a true picture of an objective event or scene but a personal and social assessment. ${ }^{37}$

This subjectivity of factual data has significance for both the postulates of the legal system and for practical lawyering. The legal persona, with its particular world view, excludes a vast body of information from its awareness. ${ }^{38}$ The legal persona is the mask through which the lawyer sees the world and through which his individual and collective experiences are viewed and filtered. ${ }^{39} \mathrm{In}$ this way, the lawyer maintains a coherent world view by selecting facts and excluding those which are unacceptable.

The lawyer's subjective manipulation of facts is analogous to the work of the historian. A lawyer typically obtains his facts from a client and then reviews, selects, organizes, and synthesizes these facts into a coherent and manageable form. Legal briefs, for example, are little more than historical documents, recounting an event and the temporarily prevailing rules that govern the event. ${ }^{40} \mathrm{Law}$ yers do not even attempt an objective history by selecting "true" factual statements. The adversary nature of the legal system requires the attorney to employ only those facts-with a judicious reordering of unfavorable facts-that will advance the cause of his client. $^{41}$

${ }^{3}$ Many social scientists maintain that facts are in part constructions of the intellect and relative to the context in which they are formulated. See, e.g., S. GREER, supra note 34, at 32-33; Franck \& Gold, The Limits of Perceptual Objectivity in International Peace Observation, 33 Law \& Contemp. Probs. 183 (1968) (reviewing theories of the subjective nature of visual perception).

Philosopher Susanne Langer characterizes sensory data as "primarily symbols." S. LaNGer, PhiLosophy in a New Key 29 (2d ed. 1951). Reality in this view is socially constructed. Thus, "the edifice of human knowledge stands hefore us, not as a vast collection of sense reports, but as a structure of facts that are symbols and laws that are their meanings." Id.

s Scholars in the field of developmental psychology have commented on the exclusionary features of a particular "world view":

Considerations of developmental psychology provide the basis for the possibility that the organism has exercised a considerable selection over what features of the world it gives the priority of its attention and the structuralization of its language. That the view of the world thus obtained is relative, rather tban absolute, and incorrect in certain applications is held by many tbeoretical physicists.

Deikman, Bimodal Consciousness, in The Nature of Human Consciousness 67, 84 (R. Ornstein ed. 1973). See generally M. BARKUN, supra note 18, at 78.

3o See Rutter, A Jurisprudence of Lawyers' Operations, 13 J. Legal Educ. 301, 319 (1961). See generally J. Frank, supra note 14.

"Law itself "is an incurably historical enterprise." J. Noonan, Persons and Masks of the LAw 152 (1976).

"See also I. Berlin, Historical InevitabiltTy 5-30 (1954).

The writing of history, like the drafting of legal briefs, involves the bighlighting of a few, 
In addition to the adversary nature of the legal system that reinforces partisanship and nonobjectivity, the method of analysis that lawyers use necessarily is subjective. Generally, legal analysis begins with the definition of the problem. Yet the very questions asked necessarily restrict and dictate the theories used to solve the problem. ${ }^{42}$ Although subjectivity inspires the questions posed for resolution and shapes the "facts" upon which the legal process operates, the legal system assumes that "facts" mirror reality and provide an objective basis upon which to invoke the legal process.

One theory that both clarifies and partially explains this imposition of one's subjective view of the world onto the external world is the psychoanalytic theory of projection. The creation of our external world by way of projection is a complex phenomenon with a basis in the operation of the ego ${ }^{43}$ and the superego ${ }^{44}$ of the individual psyche. Projection is viewed as psychic energy directed outward, effectuating the externalization of psychic content. Projection performs a number of different functions, including acting as a defense mechanism, but "it also comes into being where there are no conflicts. The projection of inner perceptions to the outside is a primitive mechanism which, for instance, also influences our senseperceptions . . . in shaping our outer world." 45

selected events. Levi-Strauss dismisses the possibility of completely reconstructing historical events:

What is true of the constitution of historical facts is no less so of their selection. From this point of view, the historian and the agent of history choose, sever and carve them up, for a truly total history would confront them with chaos. ... In so far as history aspires to meaning, it is doomed to select regions, periods, groups of men and individuals in these groups and to make them stand out, as discontinuous figures, against a continuity barely good enough to be used as a backdrop. . . . What makes history possible is that a sub-set of events is found, for a given period, to have approximately the same significance for a contingent of individuals who have not necessarily experienced the events and may even consider them at an interval of several centuries. History is therefore never history, but history-for. It is partial in the sense of being biased even when it claims not to be, for it inevitably remains partial-that is, incomplete-and this is itself a form of partiality.

Levi-Strauss, History and Dialectic, in The Structuralists: From Marx to Levi-Strauss 209, 222-23 (R. DeGeorge \& F. DeGeorge eds. 1972) (footnote omitted).

12 See K. Carlston, Law and Organization in World Society at vi-vii (1962).

${ }^{13}$ Arguably, Freud's later formulations of the ego create a model of the ego as projector. See Bergan \& Rosenberg, The New Neo-Freudians: Psychoanalytic Dimensions of Social Change, 34 PsYcH. 19, 29 (1971). "Objects in the environment are not really dealt with as being integral or separate from the self, but, rather, derive their meaning as receptacles for projected unconscious material." Id. at 31-32.

"For an analysis of the superego as a bridge to the social sciences, see T. Parsons, Social Structure and Personality 31 (1964); P. Roazen, supra note 1, at 190.

${ }^{15}$ S. Freud, Totem and Taboo, in The Basic Wratings of Sigmund Freud 805, 857 (1938). 
The significance of viewing law as a projection of mental processes and structure immediately becomes apparent. ${ }^{46}$ If law is constructed through a projective mechanism, law is neither fixed in nature nor external to man but is dependent upon the formation and evolution of the psyche. ${ }^{47}$ Edgar Bodenheimer has observed that "the law is not a pure fact of physical or psychological reality which can be explained fully by means of an analytic description of cause-effect relations. It is, to a considerable extent, a purposeful creation of the human mind." 48 Law in this sense is not a "given" or a natural condition that must be accepted. Rather, it is a projection first of structure and second of unconscious needs. ${ }^{49}$

See generally Novick \& Kelly, Projection and Externalization, in 25 The Psychoanalytic Study or the ChILd 69 (1970); van Lennep, The Four-Picture Test, in AN Introduction to Projective Techniques 149, 153 (H. Anderson \& G. Anderson eds. 1951).

By systematically obtaining and reviewing an individual's projections onto external objects, therapists gain insight into that individual's psychic functioning. See Holt, The Thematic Apperception Test, in An Introduction to Projective Techniques 181, 211 (H. Anderson \& G. Anderson eds. 1951).

"For a discussion on the introjection of legal constructs, see L. PospisiL, ANTHropozogy of Law 197-209 (1971). See also D. Easton \& J. Dennis, Children in the Political System: Origins of Polttical Legttimacy (1969); R. Hess \& J. Torney, The Development of Political Attitudes in Children (1967); J. Piaget, The Moral Judgment of the Child (1965).

"A number of scholars have considered the "internal/external" dichotomy (internal forces vs. external behavior) in law and psychology. See, e.g., Goldstein, Psychoanalysis and Jurisprudence, 77 YALE L.J. 1053, 1054 (1968).

Legal techniques for resolving a social conflict concentrate on modifying the relationship of the persons by using resources from social institutions, such as courts and legal sanctions which impose external constraints on conduct. Psychiatry approaches conflict resolution by attempting to draw upon the patient's inner resources for strengthening his capacities to accommodate himself to the demands of the relationship and external environment. Law, that is, does not try to change the person but tries to modify the environment in ways that will better meet the person's needs. Psychiatry tends to accept the environment as it is and tries to alter the person, his feelings, attitudes, and expectations, so that he may adjust to the demands of the environment with less conflict.

Baernstein, Functional Relations Between Law and Psychiatry-A Study of Characteristics Inherent in Professional Interaction, 23 J. Legal Educ. 399, 417 (1971).

13 E. Bodenheimer, Power, LAw, ANd Society 3 (1973).

"A number of contemporary theorists have moved beyond psychoanalytic theory to examine the innate structures that influence hoth the unconscious mind and cognitive processes. Professor Donald Hermann, for example, has recently proposed a structural approach to legal reasoning that urges the viability of looking beyond the personal unconscious for new perspectives on jurisprudence. Hermann theorizes:

A structural approach provides a system wherein the data supplied by factual disputes and their resolution can be organized and characterized, thereby forming a body of general rules and precedents that constitutes a coherent legal system. The articulation of a system of rules and decisions, in turn, can be seen as both the result of structuring 
II.

To this point only those aspects of the legal persona created by projection of internal forces outward have been discussed. But the legal mask is more than a product of the individual lawyer's orientation in the world: it encompasses a social ideal of the legal mind and legal character that time, period, and culture create and transform. The legal mask is not only a "cover-up" of the self by the self but a result of the self in unconscious conspiracy with society. Social expectations call it forth; social pressures reinforce and preserve it.

\section{A. Roles and the Legal Persona}

A deeper insight into the nature of the legal persona can be attained by studying the social roles lawyers play. ${ }^{50} \mathrm{~A}$ "role" is a pattern for conduct in a particular social position: role behavior is derived from the demands and expectations of those who interact with an individual in a particular setting. ${ }^{51}$ A role constitutes in sum an "organized system of participation of an individual in a social system, with special reference to the organization of that social system as a collectivity." 52

Through membership in a profession, the individual acquires a sense of "identity to the role and solidarity" with other members. ${ }^{53}$

activity and, through its development and use in decisionmaking, a part of the structuring activity itself.

Hermann, A Structuralist Approach to Legal Reasoning, 48 S. CAL. L. REv. 1131, 1133 (1975) (footnotes omitted).

so See Elkins, Book Review, 30 Vand. L. REv. 923, 928-29 (1977). For a description of a firstyear course in law school that explores lawyers' roles and personal relations, see Greenebaum \& Parsloe, Roles and Relations in Legal Practice, 28 J. Legar Educ. 228 (1976).

${ }^{31}$ See Wallace, An Excursion into the Affinities Between Law and the Behavioral Sciences, 18 J. Legal Educ. 43, 48 (1965); Watson, The Quest for Professional Competence: Psychological Aspects of Legal Education, 37 U. CrN. L. REv. 93, 105 (1968). The lawyer's fascination with rules also molds the lawyer's role.

A role can be viewed as a master rule which reconciles and directs the actions of those who take it. ... [A] typical role very often consists of many specific rules which the role-player will have to follow. It can be said, therefore, that a major function of roles is to help us decide, when in doubt, just what rules are applicable to situations with which we must deal.

W. Bishin \& C. STONE, supra note 14, at 807.

52 Parsons, Definitions of Health and Illness in the Light of American Values and Social Structure, in Patients, Physicians, and Iluness 97, 99 (E. Jaco ed. 1972).

ss Apter, Ideology and Discontent, in IDEOLOGY AND DiscoNTENT 15, 42 (D. Apter ed. 1964). For a psychological perspective, see A. WATSON, PSYchiatry fOR LAWYERS $11-14$ (1968). For commentaries on the sociology of professionalism, see generally E. HugHEs, MEN AND THEIR Work (1958); W. Mcore \& G. Rosenblum, The Professions-Roles and Rules (1970); T. 
Attributes and values of the profession mold and structure the lawyer's role. The collection of individuals, in this case lawyers, with similar masks, creates something greater than the sum of the individuals organized: the profession attains an integrity and status as a community within a community. ${ }^{54}$ And it is through the professional mask (which signals to clients that the lawyer has the requisite knowledge and skills) that the lawyer is able to play his role..$^{55}$

There is a dimension to each individual lawyer that cannot be defined by societal expectations which roughly define the legal role. To locate the individual within the legal role, one must look beyond the "fit" of the mask; one must move imside. Within, one encounters the individual's self-identity-the psychological orientation to role. ${ }^{56}$ One may find that the lawyer identifies with his social role as lawyer or perhaps that he has simply adopted a temporary orientation in the world, playing out the legal persona for a fee.

The lawyer plays other roles of obvious importance outside the legal fraternity-in his private activities and in his relationships with family, friends, and neighbors. ${ }^{57}$ Here one must consider "[t]he lawyer's sense of himself as a person [which] is broader and deeper than his sense of himself as a lawyer." ${ }^{58}$ Both private roles and identity, and the values associated with the self constantly shape and define the lawyer's professional life consciously and unconsciously. Unconsciously, the individual may be motivated to select a profession in which certain kinds of relationships are likely and where certain personal needs (e.g., power, self-esteem, control) are met. ${ }^{59}$ Andrew Watson has suggested that people choose law as

Parsons, The Professions and Social Structure, in Essays in Sociological Theory 34 (rev. ed. 1954); M. Weber, ON LAW In Economy and Society 198-223 (1954); F. Znaniecki, The SOCIAL Role of THe MaN OF KNOWLBdge (1940).

st See Wallace, supra note 51, at 47. Professional status may also cause problems because group norms define individual behavior. "Working in groups is notoriously difficult. Problems of autbority, dependency, intimacy and security, among others, are acute for group members. Group myths and unstated assumptions may govern conduct, making more difficult the accomplishment of work." Greenebaum, Attorneys' Problems in Making Ethical Decisions, 52 IND. L.J. 627, 632 (1977).

ss See M. Argyle, Social IntERAction 368 (1969).

so Thomas Shaffer has noted that "[t]he role concept is sociological-seen from the outside in; the identity concept is psychological-seen from the inside out." Shaffer, Christian Theories of Professional Responsibility, 48 S. CAL. L. REv. 721, 731 (1975). He offers a simple means of visualizing role and identity: "If I close my eyes and imagine a lawyer, I expose myself to a role. If I close my eyes and see me, I expose myself to an identity." Id.

s7 See Bresnahan, Theology and Law: A Deeper Understanding of Vocation, 7 CAP. U.L. Rev. 25, 27 (1977).

ss Sbaffer, supra note 56 , at 735.

st See Watson, supra note 51, at 94-95. See generally J. Frank, supra note 26, at 57-92. 
a vocation because it gives them an opportunity to "operate from a position of power and authority, as they organize, conceptualize, and manipulate the social forces known as law." Wo Watson has also observed in lawyers "the wish to create orderliness in ideas, institutions, and relationships." ${ }_{11} \mathrm{He}$ cautions that "perhaps some of this need for order ... may occasionally cause problems through forcing premature decisions about clients, their needs, and their wishes."

Personal identity and professional role interact in other ways. For example, many lawyers enter the profession with the hopes of rendering service to clients and of furthering social justice. ${ }^{83}$ These goals come into direct conflict with the need to derive personal income and attain financial success from the provision of client service.$^{64}$ The economic conflict of interest between a lawyer and his client raises a serious question concerning the ability of a lawyer to represent the best interests of the client. "Simply put, a quick settlement is often in the lawyer's financial interest, while waiting the insurer out is often in the client's financial interest." ${ }^{65}$ In addition, an economic status tied to client fees preserves a conservative orientation in the profession because many lawyers are unwilling to jeopardize their financial security. "This unwillingness tones down the would-be radical, 'liberalizes' him and links him with conservatives in working in the system."

so Watson, The Lawyer as Counselor, 5 J. FAM. L. 7, 9 (1965). See also S. ScheingoLd, supra note 22, at 158-59; McDougal, Beware the Squid Function, 1 Learning \& L., Spring 1974, 16 , at 18.

"Watson, supra note 60, at 10. See also S. Scheingold, supra note 22, at 159.

62 Watson, supra note 60 , at 10.

as See generally T. Shaffer, The Planning and Drafting of Wills and Trusts 10-14 (1972). The lawyer's desire to help others raises questions about self-esteem. For example, can a person without the basic security derived from self-esteem "help" others? How does the level of self-esteem affect the lawyer's identification with others, for example, with judges, important clients, opposing counsel?

w This conflict has certain psychological dimensions. See A. WaTson, supra note 53, at 18. In the world of adult reality, success, economic security, and a sense of individual worth and well-being, relate to the capacity for accomplishing productive, creative, and valuable work for others. ... A confused sense of guilt causes some professional people to feel that it is vaguely immoral to make money. Parsons describes this phenomenon and its sociological implications and points out that there is a common feeling among professionals that, when a person performs a task which is socially valuable, he should not be rewarded as greatly as if he were a "businessman."

Id. at 18-19. Cf. Shaffer, supra note 56, at 734 (discussing the conflict between a lawyer's professional and personal lives).

is See D. Rosenthal, Lawyer and Client: Who's in Charge? 96 (1974) (study of personal injury lawyers indicating that the economics of prolonged litigation may prompt the lawyer to settle quickly, contrary to the client's financial interests).

" Bonsignore, supra note 31 , at 140. 
Underlying the conflict between the private and professional lives lies a more fundamental tension between professional work and private life. ${ }^{67}$ This tension or conflict can be visualized as intersecting circles; the area of intersection represents a merger of the lawyer's professional and private lives. The traditional model of professionalism depicts the lawyer's public and personal lives as largely mutually exclusive..$^{68}$ This model is consistent with the attributes of the professional mask: the lawyer must be detached, objective, unemotional, and in control of the client. Here the legal persona is a kind of facade for the public, a mask for the private self of feelings.

The legal persona, however, can touch the private life of the self profoundly. Commonly, the legal persona dominates the individual's personality. ${ }^{69}$ Such a lawyer eats, breathes, and sleeps law. $\mathrm{He}$ "talks like a lawyer," "thinks like a lawyer," and for good measure dresses like a lawyer. In such a case of psychological identification, the legal persona is internalized and "becomes indistinguishable at a psychological level from other disguises of the self."70 The effects of overidentification with the lawyer's role lead to rigidity and an inability to change masks as required by society. Ultimately, overidentification with the professional mask may cause psychological problems. ${ }^{71}$ Because the lawyer's role is invested with so much status and prestige and because the mask fits so well, the danger of overidentification with the legal persona may not be apparent to the individual. ${ }^{72}$

" See generally F. Marks, The Lawyer, the Public, and Professicnal Regponsibulty 24142 (1972); Reisman, supra note 4, at 666.

os "Many people lead dual lives, one which is dominated by the persona, and one which satisfies other psychic needs." C. Hall \& V. Nordby, A Primer of Jungian Psychology 45 (1973).

While manifestly participating in one system of roles, the individual will have some capacity to hold in abeyance his involvement in other patterns, thus sustaining one or more dormant roles that are enacted roles on other occasions. This capacity supports a life cycle, a calendar cycle, and a daily cycle of role enactments; such scheduling implies some jurisdictional agreements as to where and what the individual is to be when. This role-segregation may be facilitated by audience-segregation, so that those who figure in one of the individual's major role-sets do not figure in another, thereby allowing the individual to possess contradictory qualities.

E. GoFrman, supra note 5, at 90-91.

"See generally id. at 89-90.

7J. Noonan, supra note 40 , at 22.

" "At the extreme, the ... splitting off of logic, common sense, and rationality from the deeper layers of the personality produce the compulsive-obsessive person, the compulsively rational person, the one who can't live in the world of emotion at all ..." A. MASLOW, THE Farther ReAches OF HUMAN NATURE 87 (1961).

72 Neurotic overidentification should not be confused with a healthy integration of profes- 
Yet another possible relation between roles and self exists: the diverse professional roles of the lawyer and the conflicts of professional and private lives create an environment of constant change-from role to role, from professional to private to professional life. Lawyers reasonably might be compared to the "shapeshifting" figure of Greek mythology-Proteus. Psychiatrist Robert Lifton has used the concept of "Protean man" as the metaphor for "an emerging psychological style." "This Protean style is "characterized by an interminable series of experiments and explorations, some shallow, some profound, each of which can readily be abandoned in favor of still new, psychological quests." 74 In essence, the Protean style is the wearing of many masks and the experiencing of the psychological consequences. ${ }^{75}$

Erik Erikson has assessed these problems of overidentification with roles and self-identity within role-playing inherent in the Protean style:

But what if role-playing becomes an aim in itself, is rewarded with success and status, and seduces the person to repress what coreidentity is potential in him? Even an actor is convincing in many roles only if and when there is in him an actor's core-identity-and craftsmanship. Comparably, there may well be some character types who thrive on Protean possibilities .... [A] Protean personality today may, in fact, be an attempt . . . to adjust to overwhelming change by a stance of deliberate changeability, of maintaining the initiative by playing at change so as to stay ahead of the game..$^{78}$

The concept of Protean man aids in understanding a profession in which roles are so diverse. The lawyer is counselor, advisor, friend, negotiator, advocate, writer, and problem solver. The paradox for the lawyer lies in the quest for an identity in the midst of constant change. Even in the original Protean personality, however,

sional roles and private self. Some people may be "self-actualizing" individuals who "assimilate their work into the identity, into the self, i.e., work actually becomes part of the self, part of the individual's definition of himself." A. Maslow, Eupsychin ManaGEMENT: A JOURNAL 1 (1965).

The integration of professional and private lives may also create ethical dilemmas. "Coping with the resulting internal conflicts is a part of every attorney's personal agenda." Greenebaum, supra note 54, at 630. See generally Watson, Lawyers and Professionalism: A Further Psychiatric Perspective on Legal Education, 8 U. Mich. J.L. Rer. 248 (1975).

73 R. LiFTon, Boundaries 37 (1969).

"Id. at 44.

${ }^{75}$ See id. at 45.

7 E. Erikson, Dimensions of a New Identity 106-07 (1974). 
there was a "core-identity in the multiplicity of elusive roles." For the lawyer, legalism as a world view provides the overarching framework within which he dons and discards new roles and within which the various contradictory tensions in and among the roles converge. ${ }^{78}$ The challenge for the lawyer is to resolve not only these tensions but the tensions that arise between his professional roles and his private life. From his "shape-shifting" posture, the lawyer must take care to retain certain values that mark him as a sensitive, thinking being. Otherwise,

The neglect or ignoring of certain human values in legal education and the lawyering process make[s] being a lawyer less than the full and rich human experience it can be for the practicing professional. The difference may be between lawyering as a narrow and unfulfilling professional role and lawyering as a place for the expression of one's own humanness. ${ }^{79}$

\section{B. The Persona and the Client}

To understand the nature of the lawyer's professional role, his interpersonal relationships must be considered. Even the sociologist will concede that a "role cannot exist without one or more relevant other-roles toward which it is oriented"; ${ }^{80}$ the lawyer cannot scrutinize himself or be scrutinized in a social vacuum. ${ }^{81}$ Moreover, as

"Id. at 106.

7 Interestingly, Erik Erikson describes Thomas Jefferson as a Protean man and suggests that Jefferson's various contradictory characters and roles ("farmer and architect, rebel and aristocrat, statesman and philospher, American and classicist") were held together by a certain "steadfastness of character." Id. Although Robert Lifton, using the concept of Protean man as a psychological tool, suggests that no "set of beliefs . . can command his [Protean man'sl allegiance for more than a brief experimental interlude," he admits that "much within him must remain constant in order to make possible his psychological flux." R. LIFToN, supra note 73 , at 54,62 .

71 J. Himmelstein, Reassessing the Lawyering Process-Proposal for a Project on the Application of Humanistic Educational Psychology to the Teaching of Law I-20 (Dec. 1976) (unpublished ms.) (copy on file with the Virginia Law Review Association).

so Turner, Role-Taking: Process versus Conformity, in Human Behavion \& Soctal Procrsses 20, 23 (A. Rose ed. 1962).

st Theodore Reik states that "[s]elf-observation . . . originates in the awareness of being observed. The intermediary stage between the observation of others and self-observation is thus the realization that one is observed by others." T. REIK, ThE SEARCH WITHIN 250 (1956). See also K. Horney, Neurosis AND HUMAN GROWTH 291-308 (1950). The concept of viewing others viewing self as stated here has been referred to as the "recycling dyadic process." In this process:

The perceiver, in some sense aware of many of the general properties of the other person (consciousness, mind) or of his specific attributes (for example, generosity) has to allow for the fact that he himself, with similar properties, is also the object of 
Anselm Strauss has ohserved, "the interactional situation is not an interaction between two persons, merely, but a series of transactions carried on in thickly peopled and complexly imaged contests." 82 In personal interactions, the participants "perceive the situation, observe what is required with respect to the status of each, and carry out the requisite or selected line of action." 83

In the lawyer-client relationship, the elevated status accorded to the lawyer as a professional tends to diminish awareness by the parties of their individual role behaviors. As a result, attorney-client interactions are based on a relationship of inequality, with the attorney in the position of dominance.$^{84}$ Because the client has a problem and needs advice, the client's dependency may be inevitable in the beginning of the association. The lawyer is expected to intervene and apply appropriate skills and knowledge to "solve" the problem. In one sense, the client seeks to be "rescued" from his problem. ${ }^{85}$

One sociologist has concluded, however, that lawyer dominance is unfavorable to the client's best interest; ${ }^{88}$ clients who share decisionmaking with the lawyer achieve more favorable outcomes. ${ }^{87}$ In addition to this disutility, lawyer dominance may have profound psychological effects on hoth the client and the practitioner. ${ }^{88}$ The person heing helped projects certain feelings and attributes onto the helper. This projection or transference may extend the client's superficial dependence on the lawyer. ${ }^{89}$ The tendency of clients to become dependent or "hooked" on lawyers is related to the perception of the lawyer as an authority or parental figure. ${ }^{90} \mathrm{In}$ addition

perception and thought and that, as such, he influences his own object of perception. Observer and observed are simultaneously observed and observer [in] ... their reciprocal perceptions, in a continuous recycling but varying process during which each person uses the variations in himself and the other person as a means of validating his hypotheses about the other.

Tagiuri, Person Perception, in 3 The Handbook or Soclal Psychology 395, 426 (2d ed. 1969).

32 A. Strauss, Mirrors and Masks 56-57 (1959).

Id. at 55 .

Wasserstrom, supra note 7, at 16.

* See M. James \& D. Jongeward, Born to Win: Transactional Analysis with Gestalt EXPERIMENTS 85-89 (1971); Steiner, Rescue, in Love, TherapY, AND Politics 43-63 (H. Wyckoff ed. 1976).

D. ROSENTHAL, supra note 65 , at 29-61.

Id.

ss See, e.g., A. WATSON, supra note 53, at 11-14; A. WATSON, supra note 23, at 23-25.

See id.

* The client "must place himself under the authority and assistance of the lawyer, essentially in blind trust. By virtue of this fact, all the client's previous attitudes about authority and dependency will be stirred up." A. WATSON, supra note 53, at 17. See generally J. FLÜGEL, The Psycho-analytic Study of the Family 119-20 (1926); H. Lasswell, The analysis of 
to the transference of positive feelings that encourage dependency, the client may project negative feelings onto the lawyer, causing the client to be hostile and uncooperative.91

Client hostility to individual lawyers is mirrored in society's ambivalent attitudes toward lawyers. Jerome Frank found the ambivalence "a mingling of respect and derision." $\mathrm{He}$ argued that "the cynical disdain of the lawyers" is derived from "a belief that the lawyers complicate the law, and complicate it wantonly and unnecessarily, [in] that, if the legal profession did not interpose its craftiness and guile, the law could be clear, exact and certain."

Client and public ambivalence to lawyers in part may result from the mask of the legal persona. Erik Erikson has described how a facade (in this case, the legal persona) may arouse admiration "to the point of canonization." Yet it also "provides disbelief and suspicion, ranging all the way from the mild assertion that in some ways the hero seems to be human (meaning like us) to the pleasure of finding cracks in the great facade."

Client suspicion of lawyers can only be encouraged by the lawyer's rigid maintenance of his professional role. By subsuming self to mask, the lawyer alienates himself from the clients and from the

Polmtcal Bghavior 186-87 (1948). To an extent, clients may prefer a dependency relationship because they "harbor certain magical expectations, for instance, that the lawyer is able to accomplish any manipulation or transaction which the client desires." A. WATsON, supra note 53, at 17-18.

"The hostility toward lawyers may stem from uncertainty concerning proper client behavior. On the one hand, the client's dependency on a lawyer complements the client's expectation that the lawyer will take command. But at the same time, the client may expect to be treated as an equal. See D. RosEnTHat, supra note 65 , at 13-16, 43, 120-22, 151 .

22 J. Frank, supra note 26, at 3. Members of society may respect the law and not the lawyer. See Waltz, Some Thoughts on the Legal Profession's Public Image, 23 DE PauL L. REv. 651, 652 (1974). Frank finds that lawyers are respected for their role in seeking justice, social control, and the protection of life and property. "Inevitably the importance of such functions invests the legal profession with dignity." J. Frank, supra note 26, at 3.

'3 Id. at 3, 5. See Shklar, In Defense of Legalism, 19 J. LBGAL Educ. 51, $53-54$ (1966). One commentator views public suspicion, fear, and disapproval of lawyers as a function of their having more power than the average citizen. Waltz, supra note 92, at 656. Another theory explaining hostility to lawyers is "that the lawyer's words, thoughts, and convictions are, apparently, for sale and at the service of the client . ..."Wasserstrom, supra note 7, at 14 . Wasserstrom argues that it is this "verbal, role-differentiated behavior of the lawyer qua advocate [that] puts the lawyer's integrity into question in a way that distinguishes the lawyer froin the other professionals." Id. (footnote omitted). Many other causes for public condemnation of the legal profession could be catalogued. See Waltz, supra note 92. See also Waltz, The Unpopularity of Lawyers in America, 25 CLEv. ST. L. REv. 143 (1976). For a histerical perspective, see Gawalt, Sources of Anti-Lawyer Sentiment in Massachusetts, 17401840, 14 AM. J. LEGal Hist. 283 (1970).

"E. ERIKson, supra note 76 , at 54. 
vital humanity of interaction. ${ }^{95}$ This type of relationship especially is characteristic of lawyers whose selves are split into professional and private compartments. Lawyers attempt to protect themselves from the deep feelings which follow psychological identification with client concerns. Maintaining a facade of impersonal coolness precludes a confrontation of the real self of the lawyer with the client; hence, the lawyer relates to the client in terms of functional status, i.e., attorney to client.

In sum, the professional norms of objectivity and detachment isolate the lawyer from his own feelings, even though one's emotions form the core of one's being. Only through a relationship in which attorney and client interact openly and on an equal basis can both seek recognition, appreciation, respect, and value in the other as a total being. ${ }^{96}$

\section{III.}

The challenge for the individual lawyer is to realize the significance of the professional mask and how it affects him as a person ${ }^{97}$ and as a professional helper. The analysis of the legal persona has raised a number of questions: what kinds of impediments does the mask create for the attorney's private life? What meaning do lawyers give the lawyering mask and how does that meaning affect their psychological well-being? Can a lawyer perform with the mask and grow psychologically and interpersonally? Can lawyers achieve harmony between their personal and professional lives? Can legal education be used to teach the prospective lawyer about the mask and its role? ${ }^{98}$

"J John Noonan has recently used the term "mask" in a similar context. See J. Noonan, supra note 40 . Noonan views the "mask" as "classifying individual human beings so that their humanity is hidden and disavowed." Id. at 19. Noonan distinguishes his usage from that in psychology, where the mask is referred to as a disguise for the inner self or psyche. Id. at 1920. "Mask is the metaphor I have chosen for [legal] constructs, because the human face is where emotion and affection are visible if not deliberately concealed." Id. at 20. "[T] he institution of the law is an official, artificial, and formal way of dealing with people and events in the world." Eisele, supra note 14, at 380 (emphasis in original). Eisele furtler notes that the law as an institution speaks "in one-dimensional ways about people and the world." Id. at 385 .

" See id. at 398,400 .

" "When we analyse the persona we take off the mask ...." C. JUNG, Two Essays on Analytical Psychology 156 (1953).

"s Judith Shklar expresses doubt as to the efficacy of attempts by academic lawyers to "reorient the thinking of lawyers by altering legal education in America." J. SHKLAR, supra note 18, at 18. Her skepticism is based on the fact that "[t]hese proposals come mostly from academic lawyers who, like their medical-school counterparts, have a rather different view 
Although these questions presently cannot be answered categorically, a "humanistic" approach to lawyering and legal education is one context in which these questions can be considered. A humanistic approach involves "a lifelong search for understanding about yourself and your world," sonal aspects of lawyering and the potential for desirable change that exists within the individual actor. An integral aspect of the humanistic approach to law, the teaching of law, lawyers, and lawyering is the need to achieve greater insight, ${ }^{100}$ which includes an awareness of self ${ }^{101}$ and an awareness of self in interaction with others in society. ${ }^{102}$ Through self-awareness and an understanding of the legal persona the lawyer can begin to achieve the potential for becoming a humanistic helper and thinker. ${ }^{103}$

of their profession than do their client-oriented former students." Id. A sociological study of the socialization and professionalization of lawyers supports Shklar's conclusions. This study concludes that law school is only the beginning of professional socialization, with the major part of socialization following law school. Lortie, Laymen to Lawmen: Law School, Careers, and Professional Socialization, 29 HARv. Educ. REv. 352, 369 (1959).

" R. Katz, Preludes to Growth, An Exprriential Approach 13 (1973). "It involves the whole man, including his physical, emotional, and spiritual dimensions as well as his intellectual dimensions. Humanistic education can evolve into education as personal growth or education for personal growth." Id. at 13.

For a discussion of the humanistic perspective in legal education, see d'Errico, Arons, \& Rifkin, Humanistic Legal Studies at the University of Massachusetts at Amherst, 28 J. LEGAL Evuc. 18 (1976); Kershen, Humanization of Lawyers at Harvard, 61 A.B.A.J. 223 (1975); Redmount, Humanistic Law through Legal Education, 1 ConN. L. REv. 201 (1968); Redmount \& Shaffer, Learning the Law-Thoughts Toward a Human Perspective, 51 Notra Dame Law. 956, 962-69 (1976); Reich, Toward the Humanistic Study of Law, 74 Yals L.J. 1402 (1965); Savoy, supra note 31 . For a more critical and pessimistic view, see Botein, Reflections on the New Humanism in Law, 22 WAYNE L. Rkv. 1295 (1976).

iv Harold Lasswell, one of our foremost interdisciplinary legal scholars, has stated that the purpose of self-scrutiny is the clarification, formulation, adoption, and employment of "procedures whose principal role is to prepare the thinker to endure or attain a higher level of rationality." Lasswell, Clarifying Value Judgment: Principles of Content and Procedure, 1 INQUIRY 87, 96 (1958).

101 The term "self" is used by different writers and schools of psychology to refer to personality, person, mind, ego, the life theme, "I," and subjective life in general. For a review of the literature on the "self," see, for example, R. Wyure, THE SELF Concept (rev. ed. 1974). See also Interview with M. Brewster Smith, Are You an Iceberg, a Mirror or an Island? Our Many Versions of the Self, Psych. TODAY, Feb. 1976, at 74.

1102 See Redmount, Attorney Personalities and Some Psychological Aspects of Legal Consultation, 109 U. PA. L. REv. 972, 974 (1961).

${ }^{103}$ See A. Watts, The Book on the Taboo Against Knowing Who You ARe (1967). The call for greater awareness through self-exploration is not universally accepted. For example, Lewis Thomas argues that the attempt to condition autonomic bodily functions "will consume so much of our energy that we will end up even more cut off from things outside, missing the main sources of the sensation of living." L. Thomas, The Lives of a CeLl 68 (1974).

Zen Buddhism also seems to discount any concentrated focus on self. "Meditation (of the 
Self-scrutiny may take place at various levels. At its most superficial level, it is simply an intellectual effort to evaluate and gain understanding of one's role within the legal system. For example, a judge is required to engage in self-reflection to discover potential bias and personal prejudices, which could affect the outcome of a case. ${ }^{104}$ From a more theoretical level, a conscious effort of selfobservation underlies all legal obligations: the law of contracts requires one to keep one's promises; and tort and property law ensure that one will curtail activity that unreasonably endangers one's neighbors and their possessions. Finally, at the highest level, selfscrutiny is an attempt to gain awareness of one's particular world view.

Self-awareness, however, cannot be achieved solely through an understanding of the relation of self within society. Lawyers should also engage in a cognitive process more closely related to the psychodynamics of individual therapy: a process intended to increase selfawareness through insight. ${ }^{105}$ Insight, as used here,

turns inward, and occasionally gives us an inkling of the influence which our central emotions and motivations have on the very choice of and the final evaluation of what we are observing. ... True insight is the power or act of seeing into a situation and into myself at the same time: for the two are, in fact, one power, one act. ${ }^{108}$

The benefit to the lawyer from an insight into the attorney-client relationship lies in the acquired ability to understand and minimize

concentrative form) is an exercise which employs repetition to turn off the active mode of consciousness, and allows a "bypass' to be developed into the quiescent, receptive mode." Foreword (pt. 4) to The Nature of Human Consciousness 213, 214 (R. Ornstein ed. 1973). See also C. Naranjo \& R. Ornstein, On the Psychology of Meditation (1971).

in The effort to become fully conscious of one's personal biases may be more difficult than the legal system admits. Jerome Frank argues:

Our most compelling biases have deeper roots and are far better concealed from consciousness [than, for example, political biases]. They often grow out of childish aims which are not relevant to our adult status. To admit their existence would be difficult and painful. Most of us are unwilling-and for the most part unable-to concede to what an extent we are controlled by such biases. We cherish the notion that we are grown-up and rational, that we know why we think and act as we do, that our thoughts and deeds have an objective reference, that our beliefs are not biases but are of the other kind--the result of direct observation of objective data.

J. FranK, supra note 26 , at 29 (footnote omitted).

tos Karen Horney argues: "Observation and critical intelligence are no substitute for that inner certainty with reference to others which is possessed by a person who is realistically aware of himself as himself and others as themselves, and who is not swayed in his estimate of them by all kinds of compulsive needs." K. HorNEY, supra note 81, at 295.

${ }_{108}$ E. ERIKson, Life History and the Historical Moment 173 (1975). 
the unconscious aspects of decisionmaking. ${ }^{107}$ One commentator has ventured that:

[T] $t$ is surely untoward-nay, unconscionable-for the law to be the dupe of unconscious wishes, especially if these wishes reflect the primitive, irrational, archaic, and mutually contradictory ideas and impulses of early childhood. Rather, the law ought-to the greatest extent possible-[to] be a product of sober, serious, informed, reflective adult thought. Hence the more lawyers know about unconscious motivation, the more likely it is that they will be able to help the law resist the influence of immature and irrational repressed urges-and in so doing, help the law become as mature and effective as possible. ${ }^{108}$

In the psychotherapeutic or psychoanalytic sense, pursuing selfawareness through insight, turns one's focus from self-observation on a conscious level to unconscious intrapsychic phenomena. ${ }^{108}$ Psychoanalytic theory offers not only a structure for understanding internal mental processes; it also offers a technique and method of obtaining insight into those intrapsychic forces which affect decisionmaking. ${ }^{110}$ The psychoanalytic method requires a subject to re-

107 Freud demonstrated the influence of the unconscious on our actions. Our "life script" is written at least in "rough draft" during the earliest years of childhood. From psychoanalytic theory we derive understanding of the unconscious motivations which "push us into actions and feelings and responses that may be different from what we consciously desire and may even be destructive of satisfactory relations with the world around us." K. HoRNEY, SELFANALYsis 37-38 (1942). Although Freud premised the existence of these unconscious forces on his observations of psychologically disturbed patients, he argued that similar forces and energies comprise the unconscious of healtby individuals as well. See S. Freud, Psychopathology of Everyday Life, in The Basic Writings of Sigmund Freud 33 (1938).

Regardless of one's view of psychoanalysis as effective clinical treatment, the psychoanalytic frame of reference is of obvious benefit in studying the "inner" private life that affects the decisionmaking of professionals. One legal commentator has observed that "[p]sychoanalysis is a form of education to open a man to himself and to his society, to widen his area of choice and increase his responsibility as to each particular choice." Kaplan, An Academic Lawyer Plays Armchair Analyst: Some Speculations on the Relevance of Psychoanalysis to the Law, 46 NeB. L. REv. 759, 779-80 (1967).

10s Scboenfeld, Law and Unconscious Motivation, 8 How. L. Rev. 15, 25-26 (1962).

w' For a nontechnical description of the distinction between psychoanalysis and psychotberapy, see Waelder, The Scientific Approach to Case Work, in Personaltry in NAture, SocietY, AND Cụture 671, 672-73 (2d ed. C. Kluckhohn \& H. Murray eds. 1953).

110 Freud initially conceptualized mental processes as occurring at conscious, preconscious, and unconscious levels within the psyche. In this topographical view of the psyche, the preconscious was a kind of staging area and censor for conscious awareness and consisted of thoughts and memory traces that were available and subject to recall by the individual. Freud viewed the preconscious as "latent but capable of becoming conscious" as opposed to "that which is repressed and . . . not, in itself and without more ado, capable of becoming conscious." S. Freud, The Ego and the Id 5 (rev. ed. 1960). 
late experiences, feelings, emotions, and fears to an analyst who attempts to guide the patient in recognizing and understanding unconscious motivations." In this process of "working through" the unconscious material, the client obtains the insight necessary to reduce the effects of unconscious forces that underlie emotions and that oftentimes produce undesirable behavior. ${ }^{112}$ In the psychoanalytical setting, the analyst and analysand share in the effort "to arrive at an understanding of the reasons why the analysand arranges his life in the way he does." "113

Individuals engaging in self-scrutiny and a study of the legal persona outside the psychoanalytical setting obviously do not have the advantage of "working through" unconscious conflicts and repressed drives and thoughts with an analyst. The essential unresolved question is whether insight for effective self-scrutiny is possible without the encouragement and guidance of an experienced psy-

Thoughts and emotions blocked from conscious awareness and inaccessible to the individual were localized in the unconscious, maintained by the operation of a mental force Freud called "repression." In Freud's view, this mental repression actively blocked thoughts, memories, and feelings from entering consciousness. Repression thereby prevented observation of these phenomena by cognitive intellectual conscious effort. See id. at 4-5.

III Karen Horney asserts that the three primary tasks of the patient are first to: express himself as completely and frankly as possible. The second is to become aware of his unconscious driving forces and their influence on his life. And the third is to develop the capacity to change those attitudes that are disturbing his relations with himself and the world around him.

K. HORNEY, supra note 107 , at 101.

112 See 1 F. Deutsch \& W. Murphy, The CuINical InTERview 15 (1955).

Although many psychotherapists currently view Freudian psychoanalytic therapy with disfavor, psychoanalytic theory offers the only thorough explanation of the relationship between man's behavior and his motives. F. CREws, OuT of MY System 4 (1975). Crews argnes that "[w]hatever its therapeutic or even its conceptual disadvantages, only psychoanalysis has registered the psychic costs involved in man's prolonged dependency and his improvising of culture out of thwarted desire." Id. at 76. Freud must be given credit then, not for the discovery of the unconscious but for creating a systematic theory which views both the conscious and unconscious as operative in understanding behavior and the nature of man. See generally S. Freud, The Complete Introductory Lectures on Psychonnalysis (1966).

For applications of psychoanalytic theory to law, see, for example, A. Ehrenzweig, Psychoanalytic Jurisprudence (1971); C. Schoengeld, Psychonnalysis and Law (1973); Bienenfeld, Prolegomena to a Psychoanalysis of Law and Justice, (pt. 2) 53 Caurr. L. Rev. 957, 1254 (1965); Desmonde, Psychoanalysis and Legal Origins, 34 INT'L J. Psycho-ANalysis 52 (1953); Ehrenzweig, Psychoanalytical Jurisprudence: A Common Language for Babylon, 65 Colum. L. Rev. 1331 (1965); Goldstein, Psychoanalysis and Jurisprudence, 77 Yale L.J. 1053 (1968); Schoenfeld, Law and Childhood Psychological Experience, 14 CLEv.-Mar. L. REv. 139 (1965); Schoenfeld, On the Relationship Between Law and Unconscious Symbolism, 26 LA. L. REv. 56 (1965); Schoenfeld, supra note 26; Szasz, Psychoanalysis and the Rule of Law, 55 Psychonnalytic Rev. 248 (1968).

113 Schafer, Action: Its Place in Psychoanalytic Interpretation and Theory, in I The ANNuAL of PsychonNalysis 159, 187 (1973). 
choanalyst or psychotherapist. ${ }^{114}$ Many serious obstacles exist to a program of self-scrutiny and the use of insight to examine value choices. ${ }^{115}$ Insight is "held in check by custom, social training, and diverse fears" 116 as well as a lack of time and motivation to engage in sustained self-reflection. The lack of motivation to initiate a program of self-scrutiny in part may result from a psychological unwillingness to change established beliefs. For the lawyer, a process of self-scrutiny that questions the underlying assumption that laws are a product of rational decisionmaking can disrupt his view of an orderly world, and the tendency to reject such analysis to preserve a feeling of well-being is strong. In addition, resistance to unconscious materials seriously cripples insight and understanding. ${ }^{117}$ In psychoanalytic theory, the first stage of resistance begins with the rebellion against full compliance with the technique of free association, ${ }^{118}$ where the patient attempts to reserve "some region or other for himself so as to prevent the treatment from having access to it." 119 Finally, "repressive forces also keep material in the unconscious from rising to the conscious level. The ability to control[,] affect and detach oneself from the emotion that automatically sets

II Karen Horney premises the "theoretical" possibility of self-scrutiny on clinical observations of patients who have been exposed to psychoanalysis in the treatment situation and who have continued either between treatments or following a period of treatment to achieve acceptable insight through self-analysis. She does not resolve the question of whether previous exposure to psychoanalysis is a precondition to self-analysis. K. HORNEY, supra note 107, at 27-28. See K. Horney, Are You Considering Psychoanalysis? 240 (1946).

115 To suggest that true insight into one's motivations or an honest recognition of self is an easy matter "is an illusion, a belief built on wishful thinking, and a positively harmful illusion at that." K. HORNEY, supra note 107, at 18. From the outset, one must recognize that "selfanalysis is a strenuous, slow process, bound to be painful and upsetting at times and requiring all available constructive energies." Id. at 18-19.

Rudolph Arnheim, author of a brilliant work on art and perception, warns:

Reckless analysis of the self will do harm, but so will the artificial primitivism of the man who refuses to know how and why he works. Modern man can, and therefore must, live with unprecedented self-awareness. Perhaps the task of living has become more difficult-but there is no way around it.

Foreword to R. Arnhem, Art and Visual Perception at vii (1954).

it J. Luft, Of Human Interaction 14 (1969). See J. Dollard \& N. Mtluer, Personaluty AND PsYcHOTHERAPY 431-32 (1950). "There is nothing of which every man is so afraid as getting to know how enormously much he is capable of." $1 \mathrm{~S}$. KIERKEGaARD, JouRNaLS AND PAPERS 440 (1967). See G. Morgan, The Human Predicament-Dissolution and Wholeness 16 (1968).

11 See S. Freud, supra note 112, at 286-302.

118 Id. at 286-88. Resistance is not limited to the obstacles thrown in the paths of those who attempt to pry into the private recesses of our minds. It also serves as a censor to avoid conscious awareness of early childhood experiences, which have been lodged in the unconscious.

11' Id. at 288. 
in when values are touched on is not easy to develop, and is therefore rare."120

Although a program of self-scrutiny may prove difficult, the need to understand the legal persona more fully outweighs whatever obstacles may be encountered. Unstable social relationships may compel the lawyer to obtain a greater awareness of the mask. Too often the attorney overly identifies with the legal persona and is unable to take off the mask in his private life. ${ }^{121}$ Spouses and friends may find tbemselves being "cross-examined" or asked to solve a problem "legalistically" and therefore may resent the lawyer's total identification with the persona.

The need to obtain greater awareness of the legal persona also may arise from a concern that the mask is blocking the emergence of other aspects of the personality or is restricting too narrowly the way in which one is able to view the world. Students, for example, often express concern that legal education interferes with their personal lives in ways other than the immediate commitment of time and financial resources. ${ }^{122}$ The basic motivation may be to simply reclaim emotions and feelings once rejected as unlawyerlike. Through self-scrutiny and greater awareness the lawyer can see and resolve the contradictions in behavior and ideals, and can thus achieve a "harmonious matching of [his] observable behavior and his internal life of feelings, values and goals."123

Discovery of the professional mask can also affect relationships with clients. Through self-study, the lawyer achieves a greater awareness of unconscious behavioral traits that affect interactions

120 A. MitscherLich, Society Without THE FAtHer 29-30 (1963). Both Freud's and Jung's works also suggest that insight into the unconscious can be an unsettling experience. Jung, for example, describes part of the personality as a "shadow," a darker, negative, and potentially evil side which is repressed. The "shadow" is a part of the unconscious and "consists of all those uncivilized desires and emotions that are incompatible with social standards and . . . all that we are ashamed of." J. SiNOER, BOUNDARIES OF THE SouL 192 (1972). See generally E. ERIKson, supra note 106, at 20-21; C. JUNG, The UNDiscovered SeLF 60-61 (1958); E. Neumann, The Origins and History of Consciousness 351 (1970); I. Progoff, Jung's PsyChOlOGY and Its Social MEANING 107.08 (1955). Karen Horney finds, however, that "patients are well able to protect themselves from insights they are not yet able to receive," assuaging the concern that physical or psychological harms may result from self-analysis. K. HoRNEY, supra note 107 , at 33 .

${ }^{12 t}$ For one account of the disastrous effort of total identification, see C. REICH, ThE SORCERER OF Bolinas REEF (1976).

122 See, e.g., J. Osborn, The Paper Chase (1971); S. Turow, One L (1977). See generally Savoy, supra note 31.

123 W. Dyer, The Sensitive Manipulator 2 (1972). See also C. Rogers, ON Becoming A Person 308 (1961). 
with clients. As the attorney begins to assess and perhaps challenge accepted precepts of the legal persona, he will be able to view and respond to client problems from a fresh perspective. This process of assessment requires the lawyer to maintain a balance between his legal persona and his nonlegal perceptions. The lawyer, stepping away from the legal mask, gains new insight into the legal relationships that surround him. Yet he must also be careful that his new perception does not overwhelm his professionalism; the new reality must refresh, not supplant. In a sense, the lawyer must be able to draw upon nonlegal sources that sharpen his perception of his clients' problems without sacrificing the expertise on which clients depend.

Finally, one's ethical behavior and professional responsibility arguably require an awareness of self, roles, profession, and society. One commentator has theorized that self-knowledge is the very basis for ethical being: ${ }^{124}$ "Typically, the immoralist is one who lacks self-understanding, who flees from himself, who obscures his responsibility for his actions, who is impulsive and irrational . . ."125 In contrast, self-understanding can help the individual accept responsibility for his actions and thus in turn sharpen his ability to choose between the ethical and the unethical. ${ }^{126}$ At the very least then, the process of seeking a deeper sense of self is "a movement toward the ethical possibility." 127

\section{IV.}

Although laws and the legal profession are extraordinarily influential in society, ${ }^{128}$ we know very little about what it means to be a lawyer. How does a lawyer perceive his role; how does the lay public imagine it? What are the ways in which lawyers and judges traditionally conceive of and talk about their experiences, and how can these modes of thought and expression be mastered-and perhaps

124 Stack, Kierkegaard: The Self and Ethical Existence, 83 ErHics 108 (1972-1973).

125 Id. at 109.

126 See id. at 109-12.

17 Id.

126 "Modern man's life is controlled more effectively, forcefully, and in greater detail by law than by any other agency of social control." Stumpf, The Moral Order and the Legal Order, in ThE CoNCEPT OF ORDER 385 (P. Kuntz ed. 1968). During the period between 1937 and 1968, the mean percentage of lawyer-legislators in the United States House of Representatives was $57 \%$. The Senate had an even higher mean percentage: $66 \%$, with a peak of $74 \%$ in one year. Green, Schmidhauser, Berg, \& Brady, Lawyers in Congress: A New Look at Some Old Assumptions, 26 W. PoL. Q. 440, 440 (1973). See also Szanton, Public Policy and the Law: Legal Training as 'Perverse' Preparation for Policymaking Role in Government, ANTiTRust L. \& Econ. Rev., No. 3, 1973, at 51. 
modified-by individual minds? ${ }^{128}$ Can the individual lawyer give meaning to his professional work, or will that meaning inexorably be imposed from the outside?

Questions of this nature are seldom posed. This essay has attempted to survey the social sciences for thinking that directs attention to the lawyer's world view and professional mask through which the lawyer relates to society, clients, and self. The attempt is necessarily a preliminary, tentative one, sketching avenues of inquiry and posing more questions. Answers, if they exist, will come from each individual's lifetime of experience with the law and a deeper understanding of self gained through an awareness of the legal persona.

129 We carry Heaven and Hell within us; we are the cosmogonic builders. We. have choice-and all creation is our range.

For some it [is] a terrifying prospect. It would be better, think they, if Heaven were above and Hell below-anywhere outside, but not within. But that comfort has been knocked from us. There are no places to go to, either for reward or punishment. The place is always here and now, in your own person and according to your own fancy. The world is exactly what you picture it to be, always, every instant. It is impossible to shift the scenery about and pretend that you will enjoy anotber, a different act. The setting is permanent, changing with the mind and heart, not according to the dictates of an invisible stage director. You are the author, director and actor all in one: the drama is always going to be your own life, not someone else's. A beautiful, terrible, ineluctable drama, like a suit made of your own skin. Would you want it otherwise? Could you invent a better drama?

H. Miller, Sexus 428-29 (1965). 